\title{
Physiology, Ecology, Phylogeny, and Genomics of Microorganisms Capable of Syntrophic Metabolism
}

\author{
Mighael J. MaInerney, ${ }^{a}$ Ghristopher G. STrughtemeyer, ${ }^{a}$ Jessica Sieber, ${ }^{a}$ \\ Housna Mouttaki, ${ }^{a}$ Alfons J. M. Stams, ${ }^{b}$ Bernhard Schink, ${ }^{c}$ Lars Rohlin, $d$ \\ AND Robert P. Gunsalus ${ }^{d}$ \\ ${ }^{a}$ Department of Botany and Microbiology, University of Oklahoma, \\ Norman, Oklahoma, USA \\ ${ }^{b}$ Laboratory of Microbiology, Department of Agrotechnology and Food Sciences, \\ Wageningen University, Wageningen, the Netherlands \\ ${ }^{c}$ Department of Biology and Microbial Ecology, University of Konstanz, \\ Konstanz, Germany \\ ${ }^{d}$ Department of Microbiology, Immunology, and Molecular Genetics, University of \\ California, Los Angeles, California, USA
}

\begin{abstract}
Syntrophic metabolism is diverse in two respects: phylogenetically with microorganisms capable of syntrophic metabolism found in the Deltaproteobacteria and in the low G+C gram-positive bacteria, and metabolically given the wide variety of compounds that can be syntrophically metabolized. The latter includes saturated fatty acids, unsaturated fatty acids, alcohols, and hydrocarbons. Besides residing in freshwater and marine anoxic sediments and soils, microbes capable of syntrophic metabolism also have been observed in more extreme habitats, including acidic soils, alkaline soils, thermal springs, and permanently cold soils, demonstrating that syntrophy is a widely distributed metabolic process in nature. Recent ecological and physiological studies show that syntrophy plays a far larger role in carbon cycling than was previously thought. The availability of the first complete genome sequences for four model microorganisms capable of syntrophic metabolism provides the genetic framework to begin dissecting the biochemistry of the marginal energy economies and interspecies interactions that are characteristic of the syntrophic lifestyle.
\end{abstract}

Key words: syntrophy; methanogenesis; hydrogen; formate; acetogenesis; Syntrophus; Syntrophomonas

\section{Introduction}

The complete mineralization of complex organic matter to $\mathrm{CO}_{2}$ and $\mathrm{CH}_{4}$ occurs in anoxic environments where electron acceptors, other than $\mathrm{CO}_{2}$, are limiting. ${ }^{1-5}$ Examples of such environments include freshwater sediments, flooded soils, wet wood of trees, tundra, landfills, and sewage digestors. Syntrophic metabolism plays an essential role in the recycling of organic matter to methane and carbon dioxide in these environments. The degradation of

Address for correspondence: Michael J. McInerney, Department of Botany and Microbiology, University of Oklahoma, 770 Van Vleet Oval, Norman, OK 73019. Voice: 405-325-6050; fax: 405-325-7619. mcinerney@ou.edu natural polymers, such as polysaccharides, proteins, nucleic acids, and lipids, to $\mathrm{CO}_{2}$ and $\mathrm{CH}_{4}$ involves a complex microbial community. Fermentative bacteria hydrolyze the polymeric substrates, such as polysaccharides, proteins, and lipids, and ferment the hydrolysis products to acetate and longer-chain fatty acids, $\mathrm{CO}_{2}$, formate, $\mathrm{H}_{2}$. Acetogenic bacteria are likely involved in the fermentation of methanol derived from the demethylation of pectin and in the $O$-demethylation of low molecular-weight ligneous materials, and ferment hydroxylated and methoxylated aromatic compounds with the production of acetate. ${ }^{6}$ Propionate and longer-chain fatty acids, alcohols, and some amino acids and aromatic compounds are syntrophically degraded to the methanogenic substrates, $\mathrm{H}_{2}$, formate, and acetate. ${ }^{2,4}$ The syntrophic degradation of fatty 
acids is often the rate-limiting step, so it is essential that waste treatment reactors be operated under conditions that favor the retention of bacteria capable of syntrophic metabolism. Last, two different groups of methanogens, the hydrogenotrophic methanogens and the acetotrophic methanogens, complete the process by converting the acetate, formate, and hydrogen made by other microorganisms to methane and carbon dioxide. The syntrophic metabolism and methanogenesis must be tightly coupled to accomplish anaerobic degradation.

Large amounts of organic matter are microbially degraded, making methanogenesis an integral part of the global carbon cycle. Methanogenesis also occurs in the gastrointestinal tract of animals; however, organic matter is incompletely degraded to acetate and longerchain fatty acids, which accumulate and are absorbed and used by the host animal as energy sources. ${ }^{7}$ Syntrophic bacteria and acetoclastic methanogens grow too slowly to be maintained in the gastrointestinal tract. The amount of energy released and harvested per unit of biomass degraded during methanogenesis is very low. For this reason, methanogenesis is a treatment of choice for complex waste digestion, because sludge yields are low and most of the energy in the original substrates is retained in the energy-rich product, methane.

The methanogenic fermentation of complex polymeric materials involves a number of diverse, interacting microbial species. The mutual dependence between interacting species can be so extreme that neither species can function without the activity of its partner, and together the partners perform functions that neither species can do alone. Syntrophy is a specialized case of tightly coupled mutualistic interactions. The term syntrophy was first used to describe the interaction between phototrophic green sulfur bacteria and chemolithotrophic, sulfur-reducing bacteria ${ }^{8}$ and fatty acid-oxidizing microorganisms and hydrogen/formate-using microorganisms. ${ }^{3}$ In both cases, the pool size of intermediates that are exchanged between the partners (sulfur during anaerobic photosynthesis or hydrogen/formate during fatty-acid metabolism) must be kept very low for efficient cooperation among the partners to occur. We will focus on syntrophic interactions active in methanogenic environments where hydrogen and formate are exchanged between the two partners. In these syntrophic interactions, the degradation of the parent compound, for example, the fatty acid, is thermodynamically unfavorable unless the hydrogen and formate produced by the fatty-acid degrader is kept at low levels by a second microorganism, in this case, a hydrogen/formate- consuming methanogen. ${ }^{4}$ The thermodynamic basis for these interactions is discussed later in the chapter.

Under optimal conditions, the free energy changes involved in syntrophic metabolism are close to equilibrium $^{9-12}$ and the little free energy that is released in these reactions must be shared among partners. ${ }^{4}$ Growth rates and growth yields are low, 7 -month doubling time and $0.6 \mathrm{~g}$ (dry weight) per mole of methane for anaerobic methane-oxidizing consortium, ${ }^{13}$ making biochemical investigations very difficult. Thus, it is appropriate to describe syntrophy as an extreme existence, a lifestyle that involves a marginal energy economy.

In this review, we discuss syntrophic interactions operative in natural and man-made environments from the perspective of the organisms involved, their phylogenetic relationships, the range of syntrophic substrates metabolized, and the new perspectives offered by the emerging genome sequencing information for several model syntrophic microorganisms.

\section{Historical Origins}

The first example of a thermodynamically based syntrophic interaction was ethanol metabolism performed by members of the "Methanobacillus omelianskii" culture. ${ }^{14}$ Subsequently, Bryant et al. ${ }^{15}$ showed that the "Methanobacillus omelianskii" culture was in fact a coculture of two organisms, the S organism and Methanobacterium bryantii strain M.O.H. (FIG. 1). The S organism fermented ethanol to acetate and hydrogen:

$$
\begin{gathered}
2 \mathrm{CH}_{3} \mathrm{CH}_{2} \mathrm{OH}+2 \mathrm{H}_{2} \mathrm{O} \rightarrow 2 \mathrm{CH}_{3} \mathrm{COOH}+4 \mathrm{H}_{2} \\
\Delta G^{\circ \prime}=19 \mathrm{~kJ}(\text { per } 2 \text { mol ethanol })
\end{gathered}
$$

The methanogen did not use ethanol, but used the $\mathrm{H}_{2}$ made by the $\mathrm{S}$ organism to reduce $\mathrm{CO}_{2}$ to $\mathrm{CH}_{4}$ :

$$
\begin{gathered}
4 \mathrm{H}_{2}+\mathrm{CO}_{2} \rightarrow \mathrm{CH}_{4}+2 \mathrm{H}_{2} \mathrm{O} \\
\Delta G^{\circ \prime}=-131 \mathrm{~kJ}\left(\text { per mole of } \mathrm{CH}_{4}\right)
\end{gathered}
$$

When the two reactions are combined, the degradation of ethanol becomes favorable:

$$
\begin{aligned}
2 \mathrm{CH}_{3} \mathrm{CH}_{2} \mathrm{OH} & +\mathrm{CO}_{2} \rightarrow 2 \mathrm{CH}_{3} \mathrm{COOH}+\mathrm{CH}_{4} \\
\Delta G^{\circ \prime} & =-112 \mathrm{~kJ}\left(\text { per mole of } \mathrm{CH}_{4}\right)
\end{aligned}
$$

The importance of end-product removal on the thermodynamics of syntrophic ethanol, propionate, and butyrate degradation is illustrated in TABLE 1. Under standard conditions, the degradation of the substrates listed in TABLE 1 is endergonic. However, if the hydrogen partial pressure is low, then the degradation 


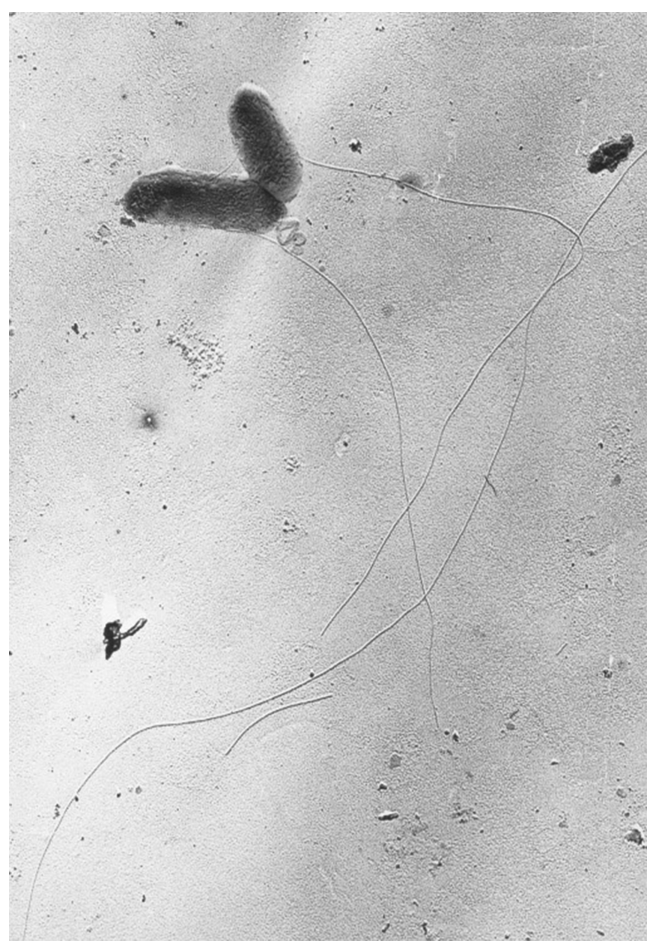

FIGURE 1. Electron micrograph of the ethanol-utilizing, rod-shaped syntrophic "S organism" isolated by Bryant and co-workers. ${ }^{15}$ It was the first bacterium capable of syntrophic metabolism to be isolated in pure culture. The $\mathrm{S}$ organism possesses a single polar flagellum whose length extends approximately 10 -fold the length of the cell body. (Photograph courtesy of Professor R. S. Wolfe.)

of these compounds is exergonic. Consistent with the thermodynamic predictions, small increases in $\mathrm{H}_{2}$ partial pressure inhibit the degradation of butyrate and benzoate by syntrophic cocultures ${ }^{4,16-20}$ and propionate degradation in methanogenic mixed cultures. ${ }^{21}$

Since this first description of syntrophic metabolism, numerous studies have led to the isolation of many novel genera and species that are capable of syntrophic metabolism. Syntrophically metabolizing bacteria have been most commonly isolated from freshwater sediments and anaerobic digesters used to treat various types of wastewater. ${ }^{22-26}$ Several molecular studies have shown that sequences related to those of bacteria capable of syntrophic metabolism are found in a wide variety of anoxic environments. ${ }^{22,24,27-30}$

The theoretical basis of syntrophic metabolism was based first on the transfer of $\mathrm{H}_{2}$ between the two partners. ${ }^{2}$ However, we now know that interspecies transfer of formate is essential. Zindel $e t a l^{31}$ showed that syntrophic metabolism can occur solely by interspecies formate transfer by growing an amino acid-fermenting

\section{TABLE 1. Reactions involved in syntrophic metabolism}

\begin{tabular}{|c|c|c|}
\hline Reactions & $\begin{array}{c}\Delta G^{\circ \prime} \\
\left(\text { footnote }^{a}\right)\end{array}$ & $\begin{array}{l}\mathrm{pH}_{2} \text { for }-\Delta G^{\prime} \\
\quad\left(\text { footnote }^{b}\right)\end{array}$ \\
\hline $\begin{array}{l}\text { Ethanol }+\mathrm{H}_{2} \mathrm{O} \rightarrow \\
\qquad \text { Acetate }^{-}+\mathrm{H}^{+}+2 \mathrm{H}_{2}\end{array}$ & +9.6 & $<10^{-1}$ \\
\hline $\begin{array}{l}\text { Propionate }^{-}+3 \mathrm{H}_{2} \mathrm{O} \rightarrow \\
\text { Acetate }^{-}+\mathrm{HCO}_{3}^{-}+ \\
\mathrm{H}^{+}+3 \mathrm{H}_{2}\end{array}$ & +76.1 & $<10^{-4}$ \\
\hline $\begin{array}{r}\text { Butyrate }^{-}+2 \mathrm{H}_{2} \mathrm{O} \rightarrow 2 \\
\text { Acetate }^{-}+\mathrm{H}^{+}+2 \mathrm{H}_{2}\end{array}$ & +48.3 & $<10^{-4}$ \\
\hline
\end{tabular}

${ }^{a}$ From Reference 104.

${ }^{b}$ The partial pressure of hydrogen needed for the reaction to be thermodynamically favorable $\left(-\Delta G^{\prime}\right)$, which was calculated with concentrations of substrate and acetate of $0.1 \mathrm{mM}$ and a bicarbonate concentration of $100 \mathrm{mM}$.

bacterium with a sulfate reducer that used formate but not $\mathrm{H}_{2}$. Syntrophic propionate degradation by Syntrophobacter fumaroxidans ${ }^{32,33}$ and butyrate degradation by Syntrophomonas (Syntrophospora) bryanti ${ }^{34}$ occurred only if the partner used both hydrogen and formate. Additionally, formate dehydrogenase levels were very high in both members of the syntrophic propionate-degrading association consistent with electron flow being coupled to interspecies formate transfer. ${ }^{35}$

Initially, bacteria that syntrophically oxidized fatty and aromatic acids were believed to be obligately dependent on the hydrogen/formate-using partner, since other substrates or electron donor/acceptor combinations could not be found that allowed the growth of the syntrophic metabolizer in pure culture. ${ }^{3} \mathrm{Mi}-$ crobes capable of the syntrophic metabolism of fatty and aromatic acids were first called obligately protonreducing acetogenic bacteria. ${ }^{3}$ As discussed elsewhere in this volume, the term acetogenic is best reserved for those bacteria that synthesize acetate from $\mathrm{CO}_{2}$ rather than from compounds with carbon-carbon bonds. Additionally, almost all of the known bacteria capable of syntrophic metabolism can be grown fermentatively in pure culture with a more oxidized derivative of their parent substrate, such as crotonate for fatty-acid degraders or fumarate for propionate degraders. ${ }^{36,37}$ Some, like the genus Syntrophobacter, have diverse metabolisms and grow fermentatively with several different substrates or by anaerobic respiration using electron acceptors, such as sulfate. ${ }^{18,23,38}$ It is noteworthy that there are a few species (Pelotomaculum schinkii, Syntrophomonas zehnderi, and Pelotomaculum isophthalicicum) that appear to be obligately syntrophic microorganisms. ${ }^{39-41}$ Verification of this prediction awaits future genome sequencing studies. 


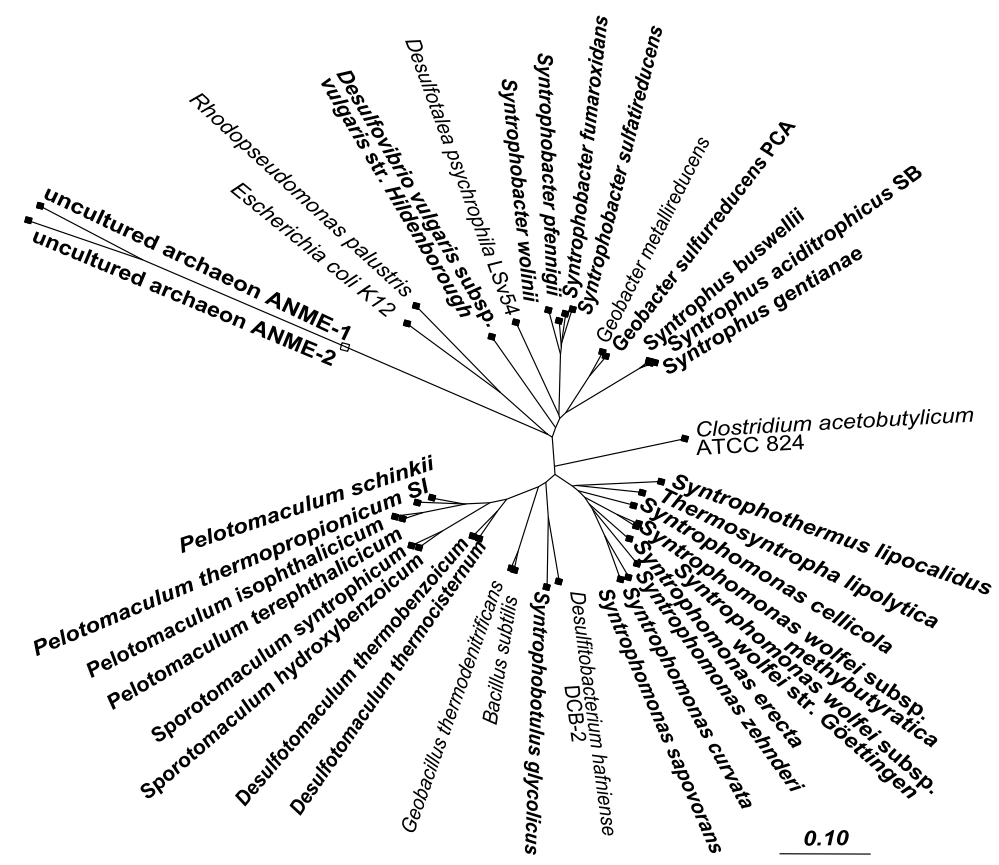

FIGURE 2. A phylogenetic tree containing representative syntrophic bacterial species. The organisms capable of syntrophy are in boldface type. The radial Neighbor-Joining tree was constructed using the ARB software package (http://www.arb-home.de/), utilizing the Greengenes 16s rRNA gene database (greengenes.lbl.gov/cgi-bin/nph-citation.cgi). ${ }^{111,112} \mathrm{~A}$ filter was created and applied to the aligned syntrophic sequences using the maximum frequency method with a $50 \%$ minimum cutoff.

\section{Phylogenetic Relationships of Syntrophic Metabolizers}

When the 16S rRNA gene sequences from bacteria capable of syntrophic metabolism are compared, it is evident that many of these microorganisms cluster with species in Deltaproteobacteria and the low G+C gram-positive bacteria (FIG. 2). Genera that contain syntrophic species within the Deltaproteobacteria include Syntrophus, Syntrophobacter, Desulfoglaeba, Geobacter, Desulfovibrio, and Pelobacter. Two other groupings of microbes that perform syntrophic metabolism fall into the low $\mathrm{G}+\mathrm{C}$ grampositive bacteria (FIG. 2). One group is composed of species within the genera Desulfotomaculum, Pelotomaculum, Sporotomaculum, and Syntrophobotulus. Syntrophomonadaceae comprises another group of microbes that perform syntrophic metabolism in the low $\mathrm{G}+\mathrm{C}$ grampositive bacteria and includes species in the genera Syntrophomonas, Syntrophothermus, and Thermosyntropha. Molecular phylogenetic analyses, ${ }^{13} \mathrm{C}$ lipid isotopic determinations, and microscopic mass spectrometric analysis identified two major groups of methanogenrelated archaea (ANME-1 and ANME-2) that anaerobically oxidize methane. ${ }^{42,43}$ The close physical associ- ation between methane-oxidizing archaea and sulfatereducing bacteria suggests a syntrophic relationship. ${ }^{44}$ Although the ANME microbes have not yet been isolated, it does appear that syntrophic metabolism occurs in both the archaeal and bacterial lines of descent.

\section{Diversity and Ecology of Syntrophic Metabolizers}

A wide variety of compounds, including saturated fatty acids, unsaturated fatty acids, alcohols, and hydrocarbons, are syntrophically degraded in methanogenic environments. ${ }^{2,38,45-47}$ Syntrophomonas wolfei was the first bacterium described that syntrophically oxidizes fatty acids in coculture with a hydrogen/formate-using microorganism. ${ }^{2,3} \mathrm{~S}$. wolfei was isolated from anaerobic digester sludge ${ }^{2,3}$ and oxidizes saturated fatty acids, ranging from C4 to C8 in length, and isoheptanoate in coculture with hydrogen-users. ${ }^{2} S$. wolfei was shown later to grow in pure culture with crotonate. ${ }^{36}$ Syntrophomonas spp. are rod-shaped, slightly motile, mesophilic, and capable of utilizing a variety of fatty acids ${ }^{48}$ (TABLE 2). These microorganisms group 
TABLE 2. Characteristics of syntrophic bacteria specializing in fatty-acid metabolism

\begin{tabular}{|c|c|c|c|c|c|c|}
\hline \multirow[b]{2}{*}{ Organism } & \multirow{2}{*}{$\begin{array}{c}\mathrm{pH} \\
\text { range }^{a}\end{array}$} & \multirow{2}{*}{$\begin{array}{l}\text { Temperature } \\
\text { range }\left({ }^{\circ} \mathrm{C}\right)^{a}\end{array}$} & \multirow{2}{*}{$\begin{array}{c}\text { Spore } \\
\text { formation }\end{array}$} & \multicolumn{2}{|c|}{ Substrates used in: } & \multirow[b]{2}{*}{ Reference } \\
\hline & & & & Pure culture & Coculture & \\
\hline Syntrophomonas bryantii & $6.5-7.5$ & $28-34$ & Yes & $\mathrm{C} 4: 1^{b}$ & $\mathrm{C} 4-\mathrm{C} 11$ & $49,50,53$ \\
\hline $\begin{array}{l}\text { Syntrophomonas wolfei } \\
\text { subsp. wolfei }\end{array}$ & ND & $(35-37)$ & No & C4:1-C6:1 & C4-C8 & 2 \\
\hline $\begin{array}{l}\text { Syntrophomonas wolfei } \\
\text { subsp. saponavida }\end{array}$ & ND & ND & No & C4:1 & $\mathrm{C} 4-\mathrm{C} 18$ & 54 \\
\hline $\begin{array}{l}\text { Syntrophomonas } \\
\text { sapovorans }\end{array}$ & $6.3-8.1(7.3)$ & $25-45(35)$ & No & None & $\begin{array}{l}\text { C4-C18, C16:1, } \\
\text { C18:1, C18:2 }\end{array}$ & 55 \\
\hline Syntrophomonas curvata & $6.3-8.4(7.5)$ & $20-42(35-37)$ & No & C4:1 & C4-C18, C18:1 & 56 \\
\hline $\begin{array}{l}\text { Syntrophomonas erecta } \\
\text { subsp. sporosyntropha }\end{array}$ & $5.5-8.4(7.0)$ & $20-48(35-37)$ & Yes & C4:1 & C4-C8 & 52 \\
\hline $\begin{array}{l}\text { Syntrophomonas erecta } \\
\text { subsp. erecta }\end{array}$ & $(7.8)$ & $*(37-40)$ & No & $\begin{array}{l}\mathrm{C} 4: 1, \mathrm{C} 4+\mathrm{C} 5: 1, \mathrm{C} 4 \\
\quad+\mathrm{DMSO}\end{array}$ & C4-C8 & 57 \\
\hline Syntrophomonas zehnderi & ND & $25-40(37)$ & Yes & None & $\begin{array}{c}\text { C4-C18, C16:1, } \\
\text { C18:1, C18:2 }\end{array}$ & 41 \\
\hline Syntrophomonas cellicola & $6.5-8.5(7.0-7.5)$ & $25-45(37)$ & Yes & $\mathrm{C} 4: 1$ & C4-C8, C10 & 49 \\
\hline $\begin{array}{l}\text { Thermosyntropha } \\
\text { lipolytica }\end{array}$ & $7.5-9.5(8.1-8.9)$ & $52-70(60-66)$ & No & $\begin{array}{l}\text { C4: } 1 \text {, yeast extract, } \\
\text { tryptone, casamino } \\
\text { acids, betaine, } \\
\text { pyruvate, ribose, } \\
\text { xylose }\end{array}$ & $\begin{array}{l}\text { C4-C18, C18:1, } \\
\text { C18:2; triglycerides }\end{array}$ & 59 \\
\hline $\begin{array}{l}\text { Syntrophothermus } \\
\text { lipocalidus }\end{array}$ & $6.5-7.0$ & $45-60(55)$ & No & C4:1 & C4-C10; isobutyrate & 58 \\
\hline Algorimarina butyrica & $6.2-7.1$ & $10-25(15)$ & No & None & $\mathrm{C} 4$, isobutyrate & 25 \\
\hline
\end{tabular}

${ }^{a}$ Optimal condition is given in parentheses; ND = not determined.

${ }^{b}$ The number of carbons in the fatty acid is indicated; the number following the colon is the number of unsaturated bonds for unsaturated fatty acids. When a range of fatty acids is given, this means that the organism can use fatty acids within the indicated range of carbon numbers, but not all possibilities were tested.

phylogenetically with the low $\mathrm{G}+\mathrm{C}$ gram-positive bacteria in the family Syntrophomonadaceae. ${ }^{48}$ Despite grouping phylogenetically with the gram-positive bacteria, members of the genus Syntrophomonas have atypical cell walls ultrastructurally similar to gramnegative cell walls, ${ }^{2,48}$ but lacking lipopolysaccharides. Syntrophomonas spp. are differentiated from each other based on substrate utilization pattern and spore formation $^{41,48,49}$ (TABLE 2). Syntrophomonas are capable of forming spores including $S$. erecta subsp. sporosyntropha, S. cellicola, S. zehnderi, and S. bryantii, which was recently reclassified and was formerly described as both Clostridium bryantii and $S$. bryantii. ${ }^{41,49-53}$ All of the described species are able to grow in pure culture with crotonate except $S$. zehnderi. ${ }^{41}$ S. erecta subsp. sporosyntropha has been shown to sporulate only in coculture with methanogens, not in coculture with a sulfate reducer or in pure culture. ${ }^{52}$ S. wolfei subsp. saponavida, ${ }^{54}$ Syntrophomonas sapovorans, ${ }^{55}$ S. zehnderi, ${ }^{41}$ and Syntrophomonas curvata $^{56}$ use C4-C18 fatty acids, and S. bryantii uses C4-C10 fatty acids in coculture (TABLE 2). S. wolfei subsp. wolfei has not been shown to form spores and use C4-C8 fatty acids. ${ }^{2}$ One strain of $S$. erecta can grow in pure culture on a mixture of butyrate and pentanoate. $^{57}$

Other members of the Syntrophomonadaceae include two thermophilic genera, Syntrophothermus and Thermosyntropha (TABLE 2). Syntrophothermus lipocalidus was isolated from granular sludge in a thermophilic upflow anaerobic sludge blanket (UASB) reactor, grows optimally at a temperature of $55^{\circ} \mathrm{C}$, and metabolizes saturated fatty acids ranging from C4 to $\mathrm{C} 10$ and isobutyrate in coculture with a thermophilic hydrogenusing methanogen. ${ }^{58}$ Thermosyntropha lipolytica was isolated from alkaline hot springs in Kenya ${ }^{59}$ and grows at $\mathrm{pH}$ values of 7.15 to 9.5 and temperatures of $52^{\circ} \mathrm{C}$ to $70^{\circ} \mathrm{C} .{ }^{59}$ This organism, unlike Syntrophomonas spp. and $S$. lipocalidus, can use yeast extract, tryptone, casamino acids, and betaine in pure culture. ${ }^{59}$ T. lipolytica and S. lipocalidus both use crotonate. ${ }^{58,59}$ T. lipolytica uses olive oil, triacylglycerols, and both saturated and unsaturated fatty acids ranging from C4 to C18 in syntrophic association with hydrogen-using microorganisms. ${ }^{59}$ Both $S$. lipocalidus and $T$. 
TABLE 3. Characteristics of propionate-degrading syntrophic bacteria

\begin{tabular}{|c|c|c|c|c|c|}
\hline \multirow[b]{2}{*}{ Organism } & \multirow{2}{*}{$\begin{array}{c}\mathrm{pH} \\
\text { range }^{a}\end{array}$} & \multirow{2}{*}{$\begin{array}{l}\text { Temperature } \\
\text { range }\left({ }^{\circ} \mathrm{C}\right)^{a}\end{array}$} & \multicolumn{2}{|c|}{ Substrates used in: } & \multirow[b]{2}{*}{ Reference } \\
\hline & & & Pure culture $^{b}$ & Coculture $^{b}$ & \\
\hline Syntrophobacter wolinii & ND & ND & $\begin{array}{l}\mathrm{C} 3^{b}+\text { sulfate; } \\
\text { fumarate }\end{array}$ & C3 & 45,71 \\
\hline Syntrophobacter pfennigii & $6.2-8.0(7.0-7.3)$ & $20-37(37)$ & $\begin{array}{l}\text { C3 + sulfate, sulfite, } \\
\text { thiosulfate; lactate }\end{array}$ & $\begin{array}{l}\mathrm{C} 3 \text {, lactate, } \\
\text { propanol }\end{array}$ & 38 \\
\hline Syntrophobacter fumaroxidans & $6.0-8.0(7.0)$ & $20-40(37)$ & $\begin{array}{l}\mathrm{C} 3+\text { sulfate or } \\
\text { fumarate; fumarate }\end{array}$ & C3 & 18 \\
\hline Syntrophobacter sulfatireducens & $6.2-8.8(7.0-7.6)$ & $20-48(37)$ & $\begin{array}{l}\mathrm{C} 3+\text { sulfate or } \\
\text { thiosulfate; } \\
\text { pyruvate }\end{array}$ & C3 & 23 \\
\hline Smithella propionica & $6.3-7.8(6.5-7.5)$ & $23-40(33-35)$ & $\mathrm{C} 4: 1$ & $\begin{array}{l}\text { C3, C4, malate, } \\
\text { fumarate }\end{array}$ & 70 \\
\hline Pelotomaculum schinkii & ND & ND & None & C3 & 39 \\
\hline $\begin{array}{l}\text { Pelotomaculum } \\
\text { thermopropionicum }\end{array}$ & $6.0-8.2(7.0)$ & $37-70(55)$ & Pyruvate, fumarate & $\begin{array}{l}\text { C3, lactate, } \\
\text { various alcohols }\end{array}$ & 63 \\
\hline $\begin{array}{l}\text { Desulfotomaculum } \\
\text { thermobenzoicum subsp. } \\
\text { thermosyntrophicum }\end{array}$ & $(7.0)$ & $42-62(55)$ & $\begin{array}{l}\text { Fumarate, pyruvate, } \\
\text { C4:1 }\end{array}$ & C3, C4, benzoate & 60 \\
\hline $\begin{array}{l}\text { Desulfotomaculum } \\
\text { thermocisternum }\end{array}$ & $(6.7)$ & $41-75(62)$ & Fumarate, pyruvate & C3, C4 & 62 \\
\hline
\end{tabular}

${ }^{a}$ Optimal condition is given in parentheses. ND $=$ not determined.

${ }^{b}$ The number of carbons in the fatty acid is indicated; the number following the colon is the number of unsaturated bonds for unsaturated fatty acids.

lipolytica stain gram-negative and neither form spores. $^{58,59}$

Certain gram-positive, spore-forming, thermophilic, sulfate-reducing bacteria from the genus Desulfotomaculum and other closely related genera have also been shown to degrade a variety of compounds in syntrophic association with hydrogen-using microorganisms. ${ }^{60}$ Desulfotomaculum spp. are found in a variety of environments, including freshwater sediments, marine sediments, and have also been observed in hydrocarbon-degrading enrichments. ${ }^{60,61}$ Desulfotomaculum thermocisternum was the first described thermophile that is capable of oxidizing propionate in syntrophic association with a hydrogen-using methanogen (TABLE 3). ${ }^{62}$ Desulfotomaculum thermobenzoicum subsp. thermosyntrophicum is also capable of degrading propionate syntrophically in thermal environments (TABLE 3) ${ }^{60}$ This organism was isolated from a thermophilic anaerobic digester treating kraft-pulp wastewater, and can be distinguished from other thermophilic, syntrophic propionate oxidizers due to its ability to oxidize benzoate in the presence of sulfate. ${ }^{60}$

P. schinkii and Pelotomaculum thermopropionicum strain SI have recently been shown to degrade propionate in syntrophic association with hydrogen-using methanogens (TABLE 3). ${ }^{39,63}$ P. schinkii is currently considered to be an obligate syntrophic organism. ${ }^{39}$ P. thermopropionicum grows at $55^{\circ} \mathrm{C}$ and metabolizes fumarate and pyruvate in pure culture, and propionate, ethanol, lactate, 1-butanol, 1-pentanol, 1,3propanediol, 1-propanol, and ethylene glycol in coculture. ${ }^{63}$ Other species of in the genus Pelotomaculum include $P$. terephthalicicum and $P$. isophthalicicum (TABle 4). P. isophthalicicum has not been grown in pure culture, while $P$. terephthalicicum grows in pure culture with crotonate, 2,5-dihydroxybenzoate, and hydroquinone. ${ }^{40} P$. terephthalicicum and $P$. isophthalicicum metabolize a variety of phthalate isomers and other aromatic compounds in syntrophic association with hydrogen-using methanogens. ${ }^{40}$ P. schinkii, P. thermopropionicum, $P$. terephthalicicum, and $P$. isophthalicicum have recently been shown to group with Desulfotomaculum subcluster Ih. ${ }^{64}$ However, none of these organisms utilize sulfate as an electron acceptor. ${ }^{39,40,63}$ Expression of $d s r A B$, which encode for the alpha and beta subunits of the dissimilatory sulfite reductase, by real-time polymerase chain reaction (PCR) was observed in only one of five propionate-degrading enrichments that contained propionate degraders that group with Desulfotomaculum subcluster Ih. ${ }^{64}$ Pure cultures of P. schinkii, $P$. thermopropionicum, P. terephthalicicum, and P. isophthalicicum 
TABLE 4. Characteristics of aromatic-degrading syntrophic bacteria

\begin{tabular}{|c|c|c|c|c|c|}
\hline \multirow[b]{2}{*}{ Organism } & \multirow{2}{*}{$\begin{array}{c}\mathrm{pH} \\
\text { range }^{a}\end{array}$} & \multirow{2}{*}{$\begin{array}{l}\text { Temperature } \\
\text { range }\left({ }^{\circ} \mathrm{C}\right)^{a}\end{array}$} & \multicolumn{2}{|c|}{ Substrates used in: } & \multirow[b]{2}{*}{ Reference } \\
\hline & & & Pure culture & Coculture & \\
\hline Syntrophus buswellii & $6.5-7.5(7.1-7.4)$ & ND & $\begin{array}{l}\mathrm{C} 4: 1^{b} \text {; cinnamate; } \mathrm{C} 4: 1+ \\
\text { benzoate or } \\
\text { 3-phenyl-propionate }\end{array}$ & C4:1, benzoate & 67 \\
\hline Syntrophus gentianae & $6.5-7.5(7.1-7.4)$ & $10-33(28)$ & $\begin{array}{l}\text { C4:1, hydroquinone, 2,5- } \\
\text { diOH-benzoate }\end{array}$ & $\begin{array}{l}\text { C4:1, benzoate, } \\
\text { hydroquinone, } \\
\text { 2,5-diOH-benzoate }\end{array}$ & 69 \\
\hline Syntrophus aciditrophicus & $6.5-7.5(7.1-7.4)$ & $25-42(37)$ & $\begin{array}{l}\text { C4: } 1, \text { benzoate, } \\
\text { cyclohex-1-ene } \\
\text { carboxylate }\end{array}$ & $\begin{array}{l}\text { Benzoate, fatty acids, } \\
\text { unsaturated fatty } \\
\text { acids }\end{array}$ & 68 \\
\hline $\begin{array}{c}\text { Sporotomaculum } \\
\text { syntrophicum }\end{array}$ & $6.0-7.5(7.0-7.2)$ & $20-45(35-40)$ & C4:1; C4:1 + benzoate & Benzoate & 65 \\
\hline $\begin{array}{l}\text { Pelotomaculum } \\
\text { terephthalicicum }\end{array}$ & $6.5-7.5(6.8-7.2)$ & $25-45(37)$ & $\begin{array}{l}\text { C4:1, hydroquinone, } \\
\text { 2,5-diOH-benzoate }\end{array}$ & $\begin{array}{l}\text { Benzoate, phthalates, } \\
\text { hydroxy-benzoates, } \\
\text { 3-phenylpropionate }\end{array}$ & 40 \\
\hline $\begin{array}{l}\text { Pelotomaculum } \\
\text { isophthalicicum }\end{array}$ & $6.8-7.2(7.0)$ & $25-45(37)$ & None & $\begin{array}{l}\text { Benzoate, phthalates, } \\
\text { 3-OH-benzoate }\end{array}$ & 40 \\
\hline
\end{tabular}

${ }^{a}$ Optimal condition is given in parentheses. ND $=$ not determined.

${ }^{b}$ The number of carbons in the fatty acid is indicated; the number following the colon is the number of unsaturated bonds for unsaturated fatty acids.

also failed to yield a PCR product. ${ }^{64}$ Therefore, the inability of the isolates and enrichments to couple propionate oxidation to sulfate reduction and the lack of $d s r A B$ genes in all but one enrichment suggests that the Desulfotomaculum subcluster Ih consists of syntrophic metabolizers that may have lost their ability to reduce sulfate. ${ }^{39,40,63,64}$

Sporotomaculum syntrophicum groups with members of the Desulfotomaculum and metabolizes benzoate in syntrophic association with hydrogen-using methanogens (TABLE 4). ${ }^{65}$ S. syntrophicum does not use sulfate as an electron acceptor. ${ }^{65}$ S. syntrophicum grows in pure culture on crotonate. ${ }^{65}$ One final example of a syntrophic metabolizer that groups with Desulfotomaculum is Syntrophobotulus glycolicus. ${ }^{66}$ This microorganism oxidizes glycolate in syntrophic association with hydrogen-using methanogens. ${ }^{66}$ S. glycolicus is most commonly observed in freshwater environments, and cannot couple the oxidation of glycolate to the reduction of sulfate. ${ }^{66}$

Some gram-negative bacteria affiliated with the Deltaproteobacteria are capable of syntrophic metabolism. ${ }^{67-69}$ The first syntrophic propionate oxidizer described was Syntrophobacter wolinii, ${ }^{45}$ which was isolated from primary anaerobic digestor sludge. Three other Syntrophobacter species have been described, Syntrophobacter pfennigii from an anaerobic sludge of a sewage plant, ${ }^{38}$ Syntrophobacter fumaroxidans isolated from an anoxic sludge blanket reactor treating wastewater from a sugar refinery, ${ }^{18}$ and two strains of Syntro- phobacter sulfatireducens TB8106 and WZH410 isolated from the anoxic sludge of a reactor treating brewery wastewater or a reactor treating bean-curd wastewater, respectively. ${ }^{23}$ Syntrophobacter spp. form a monophylogenetic group that is separate from other Deltaproteobacteria, but are most closely related to group 7 of the sulfatereducing bacteria. ${ }^{18,23,38,45,70,71}$ The four species are mesophilic, nonmotile, and non-spore-forming bacteria. In the absence of a methanogen, all four species are capable of axenic growth and oxidize propionate by using sulfate or fumarate as an electron acceptor (TABLE 3). ${ }^{18,23,38,45,70,71}$ They can also grow in pure culture by fermenting fumarate, malate, or pyruvate. Syntrophobacter spp. have been observed in freshwater sediments, marine sediments, rice paddy sediments, acidic fens, and eutrophic bog and marsh sediments. $^{22,24,30,72}$ 13C-Propionate labeling studies showed that Syntrophobacter spp., Smithella spp., and Pelotomaculum spp. were active in syntrophic propionate oxidation in rice paddies. ${ }^{30}$

Smithella propionica is another propionate-degrading syntrophic microorganism in the Deltaproteobacteria (TABLE 3). It was isolated from an anaerobic filter inoculated with domestic sewage sludge enriched with propionate. Unlike Syntrophobacter, S. propionica is unable to use sulfate as an electron acceptor and needs the presence of a hydrogen user to degrade propionate. ${ }^{70}$ Syntrophobacter species degrade propionate to acetate and $\mathrm{CO}_{2}$ by using the methylmalonyl-CoA pathway. ${ }^{73}$ 
However, S. propionica ferments propionate to acetate with the production of traces of butyrate by a new pathway that involves the condensation of two molecules of propionate to form a six-carbon intermediate that is ultimately cleaved to form acetate and butyrate. ${ }^{74}$ S. propionica grows with butyrate, malate, and fumarate in coculture with a methanogen and with crotonate in pure culture.

Syntrophus spp. are rod-shaped bacteria capable of degrading aromatic compounds in syntrophic association with hydrogen-using microorganisms (TABLE 4). ${ }^{67-69}$ Syntrophus spp. are also affiliated with the Deltaproteobacteria and have frequently been isolated from sewage sludge. ${ }^{67-69}$ Syntrophus buswellii metabolizes benzoate in coculture with hydrogen-using microorganisms and crotonate in pure culture. ${ }^{67}$ Syntrophus gentianae syntrophically metabolizes benzoate, gentisate, and 3-phenylpropionate. ${ }^{69}$ Syntrophus aciditrophicus also syntrophically metabolizes benzoate, but differs from other Syntrophus spp. in its ability to metabolize a variety of fatty acids in syntrophic association with hydrogen users. ${ }^{68} S$. gentianae grows in pure culture with crotonate, producing butyrate and acetate, ${ }^{69}$ whereas S. aciditrophicus ferments crotonate to acetate and cyclohexane carboxylate. ${ }^{75}$

Molecular ecological studies suggest that Syntrophus spp. may play an important role in a number of environments. ${ }^{16,22,28,29,76}$ Sequences related to Syntrophus spp. are commonly detected in clone libraries from hydrocarbon-contaminated sites. ${ }^{16,28,29,76} \mathrm{Sev}-$ eral studies suggest that Syntrophus spp. may be involved in the degradation of benzoate, which is an important intermediate in the anaerobic degradation of aromatic hydrocarbons in hydrocarbon-contaminated sites. ${ }^{16,28,29,76,77}$ The concentration of short-chain fatty acids have been observed to increase as a result of the degradation of hydrocarbons, which could also explain why Syntrophus sequences are observed at these sites. ${ }^{17}$ Benzoate has been shown to be an important intermediate in the degradation of 3-chlorobenzoate and 2-chlorophenol, and sequences related to Syntrophus spp. tend to appear as benzoate degradation begins. $^{27}$ Syntrophus spp. sequences have also been observed in dechlorinating enrichments that contained either a mixture of trichloroethene and methanol or a mixture of vinyl chloride and methanol. ${ }^{78}$ The degradation of alkylbenzenes ${ }^{79}$ and halogenated aromatic compounds ${ }^{80}$ to methane involves a consortium of microorganisms and likely involves the activity of Syntrophus spp.

The genus Pelobacter also clusters within Deltaproteobacteria. Pelobacter spp. are predominant in sediments and sludge where syntrophic alcohol oxidation occur. $^{81}$ Pelobacter venetianus ${ }^{82}$ and Pelobacter acetylenicus $^{83}$ have been shown to syntrophically metabolize ethanol.

Syntrophococcus sucromutans is a rumen bacterium that requires an exogenous electron acceptor, either formate, methoxylated aromatic compounds, or a hydrogen/formate-using microorganism, to oxidize carbohydrates. ${ }^{84}$ Tepidanaerobacter syntrophicus was also isolated from thermophilic anaerobic digesters and degrades lactate and numerous alcohols in syntrophic association with hydrogen-using methanogens. ${ }^{85}$ This organism groups with the firmicutes, and appears to be most closely related to Thermosediminibacter spp. and Thermovenabulum ferriorganovorum. ${ }^{85}$ Syntrophic butyrate metabolism has been described in cocultures of $\mathrm{Al}$ gorimarina butyrica and hydrogen-using methanogens. ${ }^{25}$ These cocultures were enriched from psychrophilic bay sediments, and are phylogenetically related to sulfatereducing bacteria from the genera Desulfonema and Desulfosarcina. ${ }^{25}$ This same study also established syntrophic propionate enrichments from these cold sediments, but the authors were unable to isolate the propionate degrader. ${ }^{25}$

Recent molecular characterization of enrichments for syntrophic metabolizers from a eutrophic site within the Florida Everglades revealed the presence of bacterial and archaeal sequences that were either members of novel lineages or closely related to uncultured environmental clones. ${ }^{22}$ Subsequent cultivationbased and molecular studies revealed the presence of a novel Methanosaeta sp. and fatty acid-oxidizing bacteria related to Syntrophomonas spp. and Syntrophobacter spp. ${ }^{22}$

Also, hydrocarbons can be degraded syntrophically. A bacterium has been described that syntrophically degrades toluene in coculture with a sulfate reducer. ${ }^{86}$ In some environments, the anaerobic oxidation of methane involves a highly organized, multicellular structure of the methane-oxidizing and sulfate-reducing bacteria. ${ }^{44}$ More recently, Desulfoglaeba alkanexedens has been isolated, which can syntrophically degrade alkanes in coculture with methanogens. ${ }^{87}$ Hexadecane-degrading enrichments contain microorganisms phylogenetically related to Syntrophus spp. ${ }^{88}$ Other studies have shown that hydrocarbon loss is coupled to methane production, which would indicate that syntrophic metabolism must be involved. ${ }^{46,47}$

Zinder and Koch described a thermophilic acetatedegrading coculture consisting of an acetate-degrading bacterium and a $\mathrm{H}_{2}$-consuming methanogen. ${ }^{89}$ The syntrophic acetate oxidizer, strain AOR, appeared to be a homoacetogen in pure culture, producing acetate from $\mathrm{H}_{2}$ and $\mathrm{CO}_{2}$ as well as syntrophically with a 
methanogen where acetate is oxidized to $\mathrm{H}_{2}$ and $\mathrm{CO}_{2}$, suggesting that the pathway is reversible. ${ }^{90}$ Biochemical studies revealed that strain AOR uses the acetylCoA synthase pathway ("Wood-Ljungdahl" pathway), as do other homoacetogens. ${ }^{90,91}$

Other microbes that syntrophically oxidize acetate include Geobacter sulfurreducens with partners, such as Wolinella succinogenes or Desulfovibrio desulfuricans, and nitrate as the electron acceptor. ${ }^{92}$ Clostridium ultunense strain BST was isolated in pure culture with substrates typically utilized by homoacetogenic bacteria, but can also syntrophically oxidize acetate. ${ }^{93}$ Syntrophic acetate oxidation also has been observed in Thermacetogenium phaeum, which was isolated from thermophilic anaerobic digesters. ${ }^{94}$ This microorganism is phylogenetically related to Clostridium and Bacillus spp. ${ }^{94} \mathrm{~A}$ recent article described Candidatus Contubernalis alkalaceticum, which is capable of syntrophic acetate oxidation in coculture with Desulfonatronum cooperativum. ${ }^{95}$ These microorganisms were isolated from a soda lake, and appear to group phylogenetically with uncultured low $\mathrm{G}+\mathrm{C}$ gram-positive bacteria within the family Syntrophomonadaceae. ${ }^{95}$ In addition to acetate, these organisms were also observed to syntrophically oxidize ethanol, propanol, isopropanol, serine, fructose, and isobutyrate..$^{95}$

Evidence also shows that some homoacetogens are capable of syntrophic metabolism because their metabolism of methanol is affected by cocultivation with $\mathrm{H}_{2}$-consuming anaerobes. ${ }^{96,97}$ In pure culture, Sporomusa acidovorans ferments methanol and $\mathrm{CO}_{2}$ to acetate,

$$
\begin{aligned}
& 4 \text { Methanol }+2 \mathrm{HCO}_{3}^{-} \rightarrow 3 \text { Acetate }^{-}+\mathrm{H}^{+} \\
& +4 \mathrm{H}_{2} \mathrm{O} \Delta G^{\circ \prime}=-220 \mathrm{~kJ} \text { per mol }
\end{aligned}
$$

In coculture with the $\mathrm{H}_{2}$-consuming Desulfovibrio desulfuricans with nitrate, no acetate is formed, indicating that methanol is oxidized to $\mathrm{CO}_{2}$ and $\mathrm{H}_{2}$, a conversion that is only possible at a low hydrogen partial pressure. ${ }^{97}$

$$
\begin{gathered}
\text { Methanol }+2 \mathrm{H}_{2} \mathrm{O} \rightarrow \mathrm{HCO}_{3}^{-}+\mathrm{H}^{+}+3 \mathrm{H}_{2} \\
\Delta G^{\circ \prime}=+24 \mathrm{~kJ} \text { permol }
\end{gathered}
$$

Another syntrophic homoacetogen example may be Methanobacillus kuznezovii, which was described as a methanogen, but is likely to be a syntrophic coculture of a homoacetogen and a methanogen, since $M$. kuznezovii produced acetate during methanol metabolism. ${ }^{98}$

Syntrophic methanol-degrading enrichments were obtained from thermophilic digestors using cobaltdeficient medium to suppress methanogenesis. ${ }^{99}$ Moorella mulderi and a Desulfotomaculum species were iso- lated from the enrichment. ${ }^{100,101}$ Although the sulfate reducer used methanol in pure culture, it appeared to use the hydrogen produced by $M$. mulderi when grown in coculture. A syntrophic methanol-degrading coculture of a Moorella species with a $\mathrm{H}_{2}$-utilizing Methanothermobacter strain was obtained when sulfate was deleted from the cobalt-deficient medium. ${ }^{102}$ The homoacetogen grew in pure culture with methanol only when cobalt was added to the medium. ${ }^{102}$ The effect of cobalt on the growth of the Moorella species is not exactly clear. It is likely that, in the presence of cobalt, a corrinoid-containing methyltransferase is used for methanol degradation, while in the absence of cobalt, a methanol dehydrogenase is used to oxidize methanol to formaldehyde, which would not be further degraded by pure cultures. Moorella thermoautotrophica contains a methanol dehydrogenase with pyrroloquinoline quinone as the prosthetic group. ${ }^{103}$

\section{Energetics}

An intriguing aspect of the metabolism of syntrophically fermenting bacteria is the fact that they must catalyze reactions that are endergonic under standard reactions conditions (i.e., positive $\Delta G^{\circ \prime}$ ). The activity of the partner organism is required to maintain the concentrations of hydrogen, formate, and acetate low enough to permit the metabolism of the substrate by the syntrophic metabolizer to be sufficiently exergonic to support adenosine triphosphate (ATP) synthesis, anabolism, and growth. For this reason, syntrophically fermenting bacteria are excellent model organisms to study the minimum limits of microbial energy metabolism. For example, is there a minimum amount of free energy required to conserve energy in a biologically useful form to maintain viability?

Based on the energy released by the hydrolysis of ATP and the concentrations of adenylate molecules in growing bacteria, it is estimated that a free energy change of -60 to $-70 \mathrm{~kJ}$ per mol is required for the biochemical synthesis of ATP under physiological conditions. ${ }^{104}$ This amount of energy does not need to be supplied in one single step, as exemplified by the formation of ATP by substrate-level phosphorylation, but rather, can be accomplished in smaller increments, for example, by membrane-bound proton-translocating redox reactions or other exergonic reactions involving the transport of sodium ions ${ }^{105}$ that culminate in ATP synthesis through a membrane-bound ATP synthase. A ratio of three protons translocated per ATP formed has been assumed, ${ }^{4}$ although recent research on the 
structure and function of ATP synthases from different organisms indicates that this stoichiometry may vary between 3 and $5 \mathrm{H}^{+}$per ATP formed or hydrolyzed. ${ }^{106}$ Thus, the minimum increment of energy required for ATP synthesis may be as low as $12-15 \mathrm{~kJ}$ per mol, and values in the range of $15-20 \mathrm{~kJ}$ per mol reaction have been calculated for most syntrophic fermentations under insitu conditions. ${ }^{4}$ In some cases, especially in syntrophic fermentation of propionate to acetate and hydrogen, the overall energetics appear to be lower, about $-12 \mathrm{~kJ}$ per mol reaction, as calculated from insitu propionate, acetate, and hydrogen concentrations. This view may be incomplete, since formate exchange between the partners also appears to be required for syntrophic propionate fermentation. ${ }^{35}$ In experiments with resting cells of the butyrate-fermenting Syntrophus aciditrophicus in buffer, an overall free energy change as low as $-4 \mathrm{~kJ}$ per mol of butyrate was calculated, ${ }^{10}$ although there was no evidence that ATP was synthesized under these conditions. The stoichiometry of ions translocated per mole substrate consumed by the syntrophic metabolizer in addition to the stoichiometry of ions consumed in support of ATP synthesis are critical issues that remain unresolved.

One specifically fascinating syntrophic system is syntrophic acetate oxidation via $\mathrm{CO}_{2}$ and $\mathrm{H}_{2}$ as intermediates, which was first demonstrated by Zinder and $\mathrm{Koch}^{89}$ in a thermophilic reactor at $58^{\circ} \mathrm{C}$. The overall reaction yields $-35 \mathrm{~kJ}$ per mol for the entire two-step process under standard conditions $\left(25^{\circ} \mathrm{C}\right)$; at $58^{\circ} \mathrm{C}$, the energy yield increases to $-42 \mathrm{~kJ}$ per mol, which is sufficient to support the growth of the two syntrophic partners. A coculture fermenting acetate syntrophically to methane and $\mathrm{CO}_{2}$ at $37^{\circ} \mathrm{C}$ has been isolated. ${ }^{93}$ The $\Delta G^{\prime}$ for syntrophic acetate oxidation at $37^{\circ} \mathrm{C}$ is $-36 \mathrm{~kJ}$ per mol of acetate. The hydrogen concentrations indicated that the free energy change for hydrogen production from acetate was very close to the value for hydrogen use by the methanogen, indicating that the coculture partners equally shared the available energy. ${ }^{90,91}$ If this is the case, then the free energy available to each organism would be about $-15 \mathrm{~kJ}$ per reaction. The growth yields also indicated that each partner equally shared the available energy. The doubling times of the coculture was in the range of 34 weeks, which indicates that a lower limit for efficient energy transformation was being reached under these conditions.

A new thermophilic acetate-fermenting coculture was isolated in Japan, ${ }^{94}$ and enzyme measurements with this culture demonstrated that all enzymes of the Wood-Ljungdahl pathway were present under both acetate utilization and acetate formation condi- tions. Moreover, the coculture was able to immediately switch from syntrophic acetate oxidation to homoacetogenic acetate formation, indicating that the entire enzyme apparatus appears to operate in a reversible manner. ${ }^{107}$ This is the first demonstrated case of a metabolism that is entirely reversible, thus demonstrating how close to the thermodynamic equilibrium such metabolism operates. Unresolved is how these bacteria manage to make ATP by each mode. There must be unique steps linked to ATP formation in one direction that are decoupled from ATP hydrolysis in the reverse direction, possibly some switch in electron flow in the membrane. So far, these steps have not yet been identified. The complete sequencing of the genome of the bacterium involved, Thermacetogenium phaeum, as well as other syntrophic acetate oxidizers, is underway and may provide insight into this exciting phenomenon soon.

The long-disputed process of anaerobic methane oxidation appears to be a syntrophic cooperation of two microbes. ${ }^{44}$ One organism, related to methanogens, appears to operate its methanogenic-like pathway in reverse, thus oxidizing methane. The second organism is a sulfate-reducing bacterium. The calculated free energy change of this syntrophic association is very low:

$$
\begin{aligned}
& \mathrm{CH}_{4}+\mathrm{SO}_{4}^{2-}+\mathrm{H}^{+} \rightarrow \mathrm{CO}_{2}+\mathrm{HS}^{-}+2 \mathrm{H}_{2} \mathrm{O} \\
& \Delta G^{\circ \prime}=-18 \mathrm{~kJ} \text { permol }
\end{aligned}
$$

The free energy available for anaerobic methane oxidation appears to be insufficient to provide both partners with an adequate amount of energy. Only under in situ conditions, that is, about $100 \mathrm{~atm} \mathrm{CH}_{4}$, would the overall process provide enough energy to "feed" both partners, and it is only under these conditions that the process can be maintained in the laboratory. ${ }^{13}$ The preceding experimental evidence indicates that the minimum amount of energy required for synthesis of ATP must occur in small increments within the range of $-15 \mathrm{~kJ}$ per mol reaction. It may also explain why, despite numerous efforts, nobody succeeded in the past in cultivation of anaerobic methane oxidizers in the laboratory under conditions close to standard reaction conditions.

\section{Genomes of Syntrophs}

The complete genome sequences of Syntrophus aciditrophicus, S. wolfei, Syntrophobacter fumaroxidans, and Pelotomaculum thermopropionicum have been reported (TABLE 5) 108,109 (http://www.jgi.doe.gov, http://www.integratedgenomics.com). The genome 


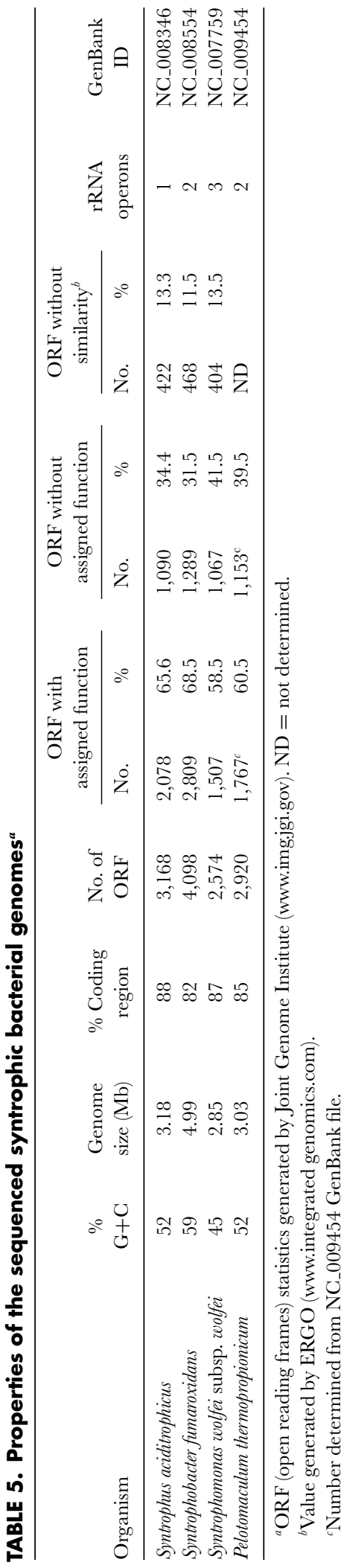

sizes are in the range of about $3 \mathrm{MB}$ for $S$. aciditrophicus, S. wolfei, and P. thermopropionicum, while that of S. fumaroxidans is higher, about $5 \mathrm{MB}$. Approximately $50-60 \%$ of the open reading frames (ORFs) were assigned tentative annotations, with the remaining $40-50 \%$ having no assigned function. It is noteworthy that a significant fraction of the ORFs in each genome lack either annotated function or similarity to proteins in any other described organism. Also noteworthy is that a best reciprocal gene comparison among these strains reveals that fewer than one-third of the genes in one strain are significantly related to those in another. ${ }^{109}$

While the detailed analysis of the genomic content of three of these genomes has not been reported as of the writing of this article, the genetic inventory of the $S$. aciditrophicus genome was recently published. ${ }^{109}$ S. aciditrophicus appears to be self-sufficient with respect to its anabolic pathways, but in contrast is highly specialized in catabolic ability, as genes for utilization of most carbon compounds by fermentation or respiration are absent. The genome of S. aciditrophicus is devoid of genes for electron transport proteins common to many anaerobic fermentative or respiratory bacteria, for example, the sulfate reducers, the nitrate reducers, or other organisms able to reduce other organic or inorganic electron acceptors. Furthermore, the genetic blueprint of $S$. aciditrophicus strain SB suggests unique and apparently undescribed mechanism(s) to metabolize its substrates (i.e., crotonate, benzoate, and cyclohexane carboxylate) to acetate and other products. A distinctive feature of syntrophic metabolism is the need for reverse electron transport. The presence of a unique ion-translocating electron transfer complex, menaquinone, and membrane-bound Fe-S proteins with associated heterodisulfide reductase domains in the genome of S. aciditrophicus suggest mechanisms to accomplish this task. Genomic analysis indicate that $S$. aciditrophicus has multiple mechanisms to create and use ion gradients such as ion-translocating ATP synthases, pyrophosphatases, decarboxylases, and hydrogenases, which would help modulate the energy status of the cells in response to varying thermodynamic conditions. The $S$. aciditrophicus genome contains genes for 17 sigma 54-interacting transcriptional regulators and 35 transcriptional regulators with a helix-turn-helix motif. ${ }^{109}$ Other gram-negative microbes have a larger number of transcriptional regulators with a helix-turn-helix motif, suggesting that $S$. aciditrophicus appears to have adopted a regulatory strategy reliant on sigma- 54 factor coupled signal transduction pathways. Interestingly, one of the operons involved in propionate metabolism in P. thermopropionicum also appears to involve sigma factor regulation. ${ }^{108}$ The complete sequencing of genomes 
for other syntrophic metabolizers is under way, and the analysis of this genomic information should provide further insights into the complexity of this important microbial lifestyle.

\section{Future Prospects}

Syntrophic associations provide ideal model systems to study microbial interactions and their role in the maintenance of community structure and functional diversity within an ecosystem. Advances in cultivation techniques, molecular ecology, and genomics and functional genomics are rapidly merging and combined should allow a comprehensive approach to understand the syntrophic lifestyle at the edge of a minimal energy existence. With these techniques, it is quite likely that we will soon uncover the extent of the diversity of microorganisms capable of syntrophic metabolism with respect to the substrates that they degrade, the variety of their metabolic pathways, and their phylogenetic relatedness. We are beginning to reveal the molecular and biochemical details needed for the syntrophic lifestyle. In particular, the recent discovery of three genes, whose expression was altered during a shift from syntrophic metabolism to sulfate reduction, has provided clues about the origins of syntrophic interactions. ${ }^{110}$ The combination of computational models with functional genomic information will allow us to interrogate the regulatory mechanisms involved in establishing and maintaining multispecies associations in order to quantify and predict the behavior of microorganisms and microbial communities in natural ecosystems.

\section{Acknowledgments}

This work was supported by grants from the $\mathrm{Na}-$ tional Science Foundation Award NSF EF-0333294 and from the U.S. Department of Energy, DE-FG0296ER20214 (MM) and DE-FG03-86ER13498 (RG).

\section{Conflict of Interest}

The authors declare no conflicts of interest.

\section{References}

1. Lowe, S.E., M.K. JaIn \& J.G. Zeikus. 1993. Biology, ecology, and biotechnological applications of anaerobic bacteria adapted to environmental stresses in temperature, $\mathrm{pH}$, salinity, or substrates. Microbiol. Rev. 57: 451-509.

2. MaInerney, M.J. et al. 1981. Syntrophomonas wolfei gen. nov. sp. nov., an anaerobic, syntrophic, fatty acid-oxidizing bacterium. Appl. Environ. Microbiol. 41: 1029-1039.

3. Mcinerney, M.J., M.P. Bryant \& N. Pfennig. 1979. Anaerobic bacterium that degrades fatty acids in syntrophic association with methanogens. Arch. Microbiol. 122: 129-135.

4. SCHINK, B. 1997. Energetics of syntrophic cooperation in methanogenic degradation. Microbiol. Mol. Biol. Rev. 61: $262-280$.

5. Schink, B. 2006. Syntrophic associations in methanogenic degradation. Prog. Mol. Subcell. Biol. 41: 1-19.

6. Dolfing, J. \& J.M. Tiedje. 1988. Acetate inhibition of methanogenic, syntrophic benzoate degradation. Appl. Environ. Microbiol. 54: 1871-1873.

7. Mackie, R.I. \& B.A. White. 1990. Recent advances in rumen microbial ecology and metabolism: potential impact on nutrient output. J. Dairy Sci. 73: 2971-2995.

8. Biebl, H. \& N. Pfennig. 1978. Growth yields of green sulfur bacteria in mixed cultures with sulfur and sulfate reducing bacteria. Arch. Microbiol. 117: 9-16.

9. Adams, G.J., M.C. Redmond \& D.L. Valentine. 2006. Pure-culture growth of fermentative bacteria, facilitated by $\mathrm{H}_{2}$ removal: bioenergetics and $\mathrm{H}_{2}$ production. Appl. Environ. Microbiol. 72: 1079-1085.

10. Jackson, B.E. \& M.J. MaInerney. 2002. Anaerobic microbial metabolism can proceed close to thermodynamic limits. Nature 415: 454-456.

11. Kleerebezem, R. \& A.J. Stams. 2000. Kinetics of syntrophic cultures: a theoretical treatise on butyrate fermentation. Biotechnol. Bioeng. 67: 529-543.

12. Scholten, J.C. \& R. ConRad. 2000. Energetics of syntrophic propionate oxidation in defined batch and chemostat cocultures. Appl. Environ. Microbiol. 66: 2934-2942.

13. Nauhaus, K. et al. 2007. In vitro cell growth of marine archaeal-bacterial consortia during anaerobic oxidation of methane with sulfate. Environ. Microbiol. 9: 187-196.

14. BARKer, H.A. 1939. Studies upon the methane fermentation. IV. The isolation and culture of Methanobacterium omelianskii. Antonie Leeuwenhoek. 6: 201-220.

15. BRYANT, M.P. et al. 1967. Methanobacillus omelianskii, a symbiotic association of two species of bacteria. Arch. Microbiol. 59: 20-31.

16. Allen, J.P. et al. 2007. The microbial community structure in petroleum-contaminated sediments corresponds to geophysical signatures. Appl. Environ. Microbiol. 73: 2860-2870.

17. Gozzarelli, I.M., R.P. Eganhouse \& M.J. Baedecker. 1990. Transformation of monoaromatic hydrocarbons to organic acids in anoxic groundwater environment. Environ. Geol. 16: 135-141.

18. Harmsen, H.J. et al. 1998. Syntrophobacter fumaroxidans sp. nov., a syntrophic propionate-degrading sulfate-reducing bacterium. Int. J. Syst. Bacteriol. 48: 1383-1387.

19. Ahring, B.K. \& P. Westermann. 1988. Product inhibition of butyrate metabolism by acetate and hydrogen in a thermophilic coculture. Appl. Environ. Microbiol. 54: 2393-2397.

20. Dwyer, D.F. et al. 1988. Bioenergetic conditions of butyrate metabolism by a syntrophic, anaerobic bacterium 
in coculture with hydrogen-oxidizing methanogenic and sulfidogenic bacteria. Appl. Environ. Microbiol. 54: 1354-1359.

21. D.P. Sмith \& P.L. McGarty. 1989. Energetic and rate effects on methanogenesis of ethanol and propionate in perturbed CSTRs. Biotechnol. Bioeng. 34: 39-54.

22. Chauhan, A., A. Ogram \& K.R. Reddy. 2004. Syntrophic-methanogenic associations along a nutrient gradient in the Florida Everglades. Appl. Environ. Microbiol. 70: 3475-3484.

23. Chen, S., X. Liu \& X. Dong. 2005. Syntrophobacter sulfatireducens sp. nov., a novel syntrophic, propionate-oxidizing bacterium isolated from UASB reactors. Int. J. Syst. Evol. Microbiol. 55: 1319-1324.

24. Juottonen, H. et al. 2005. Methanogen communities and bacteria along an ecohydrological gradient in a northern raised bog complex. Environ. Microbiol. 7: 1547-1557.

25. Kendall, M.M., Y. LiU \& D.R. Boone. 2006. Butyrateand propionate-degrading syntrophs from permanently cold marine sediments in Skan Bay, Alaska, and description of Algorimarina butyrica gen. nov., sp. nov. FEMS. Microbiol. Lett. 262: 107-114.

26. Schwarz, J.I., W. Eckert \& R. Conrad. 2007. Community structure of archaea and bacteria in a profundal lake sediment Lake Kinneret (Israel). Syst. Appl. Microbiol. 30: $239-254$.

27. BECKer,J.G. et al. 2005. The role of syntrophic associations in sustaining anaerobic mineralization of chlorinated organic compounds. Environ. Health. Perspect. 113: 310316.

28. DojKA, M.A. et al. 1998. Microbial diversity in a hydrocarbon- and chlorinated-solvent-contaminated aquifer undergoing intrinsic bioremediation. Appl. Environ. Microbiol. 64: 3869-3877.

29. Grabowski, A. et al. 2005. Microbial diversity in production waters of a low-temperature biodegraded oil reservoir. FEMS. Microbiol. Ecol. 54: 427-443.

30. Lueders, T., B. Pommerenke \& M.W. Friedrich. 2004. Stable-isotope probing of microorganisms thriving at thermodynamic limits: syntrophic propionate oxidation in flooded soil. Appl. Environ. Microbiol. 70: 57785786.

31. ZINDEL, U. et al. 1988. Eubacterium acidaminophilum sp. nov., a versatile amino acid-degrading anaerobe producing or utilizing $\mathrm{H}_{2}$ or formate. Arch. Microbiol. 150: 254-266.

32. Dong, X., G.M. Plugge \& A.J. Stams. 1994. Anaerobic degradation of propionate by a mesophilic acetogenic bacterium in coculture and triculture with different methanogens. Appl. Environ. Microbiol. 60: 2834 2838.

33. Dong, X. \& A.J. Stams. 1995. Evidence for H2 and formate formation during syntrophic butyrate and propionate degradation. Anaerobe 1: 35-39.

34. Dong, X., G. Cheng \& A.J. M. Stams. 1994. Butyrate oxidation by Syntrophospora bryantii in co-culture with different methanogens and in pure culture with pentenoate as electron acceptor. Appl. Microbiol. Biotechnol. 42: 647-652.

35. De Bok, F.A., M.L. Lujjen \& A.J. Stams. 2002. Biochemical evidence for formate transfer in syntrophic propionate-oxidizing cocultures of Syntrophobacter fumarox- idans and Methanospirillum hungatei. Appl. Environ. Microbiol. 68: $4247-4252$.

36. Beaty, P.S. \& M.J. MaInerney. 1987. Growth of Syntrophomonas wolfei in pure culture on crotonate. Arch. Microbiol. 147: 389-393.

37. Stams, A.J. et al. 1993. Growth of syntrophic propionateoxidizing bacteria with fumarate in the absence of methanogenic bacteria. Appl. Environ. Microbiol. 59: 1114-1119.

38. Wallrabenstein, G., E. Hauschild \& B. Schink. 1995. Syntrophobacter pfennigii sp. nov., new syntrophically propionate-oxidizing anaerobe growing in pure culture with propionate and sulfate. Arch. Microbiol. 164: $346-$ 352.

39. DE BoK, F.A. et al. 2005. The first true obligately syntrophic propionate-oxidizing bacterium, Pelotomaculum schinkii sp. nov., co-cultured with Methanospirillum hungatei, and emended description of the genus Pelotomaculum. Int. J. Syst. Evol. Microbiol. 55: 1697-1703.

40. QIU, Y.L. et al. 2006. Pelotomaculum terephthalicicum sp. nov. and Pelotomaculum isophthalicicum sp. nov: two anaerobic bacteria that degrade phthalate isomers in syntrophic association with hydrogenotrophic methanogens. Arch. Microbiol. 185: 172-182.

41. SousA, D.Z. et al. 2007. Syntrophomonas zehnderi sp. nov., an anaerobe that degrades long-chain fatty acids in coculture with Methanobacterium formicicum. Int. J. Syst. Evol. Microbiol. 57: 609-615.

42. Hinrichs, K.U. et al. 1999. Methane-consuming archaebacteria in marine sediments. Nature 398: $802-805$.

43. Orphan, V.J. et al. 2001. Methane-consuming archaea revealed by directly coupled isotopic and phylogenetic analysis. Science 293: $484-487$.

44. Boetius, A. et al. 2000. A marine microbial consortium apparently mediating anaerobic oxidation of methane. Nature 407: 623-626.

45. Boone, D.R. \& M.P. Bryant. 1980. Propionate-degrading bacterium, Syntrophobacter wolinii sp. nov. gen. nov., from methanogenic ecosystems. Appl. Environ. Microbiol. 40: $626-632$.

46. Ficker, M. et al. 1999. Molecular characterization of a toluene-degrading methanogenic consortium. Appl. Environ. Microbiol. 65: 5576-5585.

47. Townsend, G.T., R.C. Prince \& J.M. Suflita. 2003. Anaerobic oxidation of crude oil hydrocarbons by the resident microorganisms of a contaminated anoxic aquifer. Environ. Sci. Technol. 37: 5213-5218.

48. SobieraJ, M. \& D.R. Boone. 2006. Syntrophomonadaceae. In The Prokaryotes: An Evolving Electronic Resource for the Microbiological Community, Vol. 4. M. Dworkin, et al., Eds.: 1041-1046. New York: Springer-Verlag.

49. Wu, C., X. LiU \& X. Dong. 2006. Syntrophomonas cellicola sp. nov., a spore-forming syntrophic bacterium isolated from a distilled-spirit-fermenting cellar, and assignment of Syntrophospora bryantii to Syntrophomonas bryantii comb. nov. Int. J. Syst. Evol. Microbiol. 56: 23312335.

50. Stieb, M. \& B. Schink. 1985. Anaerobic oxidation of fatty acids by Clostridium bryantii sp. nov., a sporeforming, obligately syntrophic bacterium. Arch. Microbiol. 140: 387390. 
51. Wu, C., X. Dong \& X. LiU. 2007. Syntrophomonas wolfei subsp. methylbutyratica subsp. nov., and assignment of Syntrophomonas wolfei subsp. saponavida to Syntrophomonas saponavida sp. nov. comb. nov. Syst. Appl. Microbiol. doi: 10.1016/j.syapm.2006.12.001.

52. WU, C., X. LIU \& X. Dong. 2006. Syntrophomonas erecta subsp. sporosyntropha subsp. nov., a spore-forming bacterium that degrades short chain fatty acids in co-culture with methanogens. Syst. Appl. Microbiol. 29: 457-462.

53. ZнаO, H.X. et al. 1990. Assignment of Clostridium bryantii to Syntrophospora bryantii gen. nov., comb. nov. on the basis of a 16S rRNA sequence analysis of its crotonate-grown pure culture. Int. J. Syst. Bacteriol. 40: 40-44.

54. Lorowitz, W.H., H. Zhao \& M.P. Bryant. 1989. Syntrophomonas wolfei subsp. saponavida subsp. nov., a longchain fatty-acid-degrading, anaerobic, syntrophic bacterium. Int. J. Syst. Bacteriol. 39: 122-126.

55. RoY, F. et al. 1986. Synthrophomonas sapovorans sp. nov., a new obligately proton reducing anaerobe oxidizing saturated and unsaturated long chain fatty acids. Arch. Microbiol. 145: $142-147$.

56. Zhang, C., X. LiU \& X. Dong. 2004. Syntrophomonas curvata sp. nov., an anaerobe that degrades fatty acids in coculture with methanogens. Int. J. Syst. Evol. Microbiol. 54: $969-973$.

57. Zhang, C., X. LiU \& X. Dong. 2005. Syntrophomonas erecta sp. nov., a novel anaerobe that syntrophically degrades short-chain fatty acids. Int. J. Syst. Evol. Microbiol. 55: 799-803.

58. SeKiguchi, Y. et al. 2000. Syntrophothermus lipocalidus gen. nov., sp. nov., a novel thermophilic, syntrophic, fattyacid-oxidizing anaerobe which utilizes isobutyrate. Int. J. Syst. Evol. Microbiol. 50: 771-779.

59. Svetlitshnyi, V., F. Rainey \& J. Wiegel. 1996. Thermosyntropha lipolytica gen. nov., sp. nov., a lipolytic, anaerobic, alkalitolerant, thermophilic bacterium utilizing shortand long-chain fatty acids in syntrophic coculture with a methanogenic archaeum. Int. J. Syst. Bacteriol. 46: 1131-1137.

60. Plugge, G.M., M. Balk \& A.J. Stams. 2002. Desulfotomaculum thermobenzoicum subsp. thermosyntrophicum subsp. nov., a thermophilic, syntrophic, propionate-oxidizing, sporeforming bacterium. Int. J. Syst. Evol. Microbiol. 52: 391399.

61. Rios-Hernandez, L.A., L.M. Gieg \& J.M. Suflita. 2003. Biodegradation of an alicyclic hydrocarbon by a sulfate-reducing enrichment from a gas condensatecontaminated aquifer. Appl. Environ. Microbiol. 69: $434-443$.

62. Nilsen, R.K., T. Torsvik \& T. Lien. 1996. Desulfotomaculum thermocisternum sp. nov., a sulfate reducer isolated from a hot North Sea oil reservoir. Int. J. Syst. Bacteriol. 46: 397-402.

63. Imachi, H. et al. 2002. Pelotomaculum thermopropionicum gen. nov., sp. nov., an anaerobic, thermophilic, syntrophic propionate-oxidizing bacterium. Int. J. Syst. Evol. Microbiol. 52: 1729-1735.

64. IMACHI, H. et al. 2006. Non-sulfate-reducing, syntrophic bacteria affiliated with Desulfotomaculum cluster I are widely distributed in methanogenic environments. Appl. Environ. Microbiol. 72: 2080-2091.
65. QIU, Y.L. et al. 2003. Sporotomaculum syntrophicum sp. nov., a novel anaerobic, syntrophic benzoate-degrading bacterium isolated from methanogenic sludge treating wastewater from terephthalate manufacturing. Arch. Microbiol. 179: 242-249.

66. Friedrich, M. et al. 1996. Phylogenetic positions of Desulfofustis glycolicus gen. nov., sp. nov., and Syntrophobotulus glycolicus gen. nov., sp. nov., two new strict anaerobes growing with glycolic acid. Int. J. Syst. Bacteriol. 46: 1065-1069.

67. Fardeau, M.L. et al. 1993. Determination of the G+ C content of two Syntrophus buswellii strains by ultracentrifugation techniques. Curr. Microbiol. 26: 185-189.

68. JACKson, B.E. et al. 1999. Syntrophus aciditrophicus sp. nov., a new anaerobic bacterium that degrades fatty acids and benzoate in syntrophic association with hydrogen-using microorganisms. Arch. Microbiol. 171: 107-114.

69. SzewZyK, U. \& B. Schink. 1989. Degradation of hydroquinone, gentisate, and benzoate by a fermenting bacterium in pure or defined mixed culture. Arch. Microbiol. 151: $541-545$.

70. LiU, Y. et al. 1999. Characterization of the anaerobic propionate-degrading syntrophs Smithella propionica gen. nov., sp. nov. and Syntrophobacter wolinii. Int. J. Syst. Bacteriol. 49: 545-556.

71. Wallrabenstein, C., E. Hauschild \& B. Schink. 1994. Pure culture and cytological properties of Syntrophobacter wolinii. FEMS Microbiol. Lett. 123: 249-254.

72. LoY, A. et al. 2004. Microarray and functional gene analyses of sulfate-reducing prokaryotes in low-sulfate, acidic fens reveal cooccurrence of recognized genera and novel lineages. Appl. Environ. Microbiol. 70: 6998-7009.

73. Houwen, F.P. et al. 1987. 13C-NMR study of propionate degradation by a methanogenic coculture. FEMS Microbiol. Lett. 41: 269-274.

74. DE BoK, F.A.M. et al. 2001. Pathway of propionate oxidation by a syntrophic culture of Smithella propionica and Methanospirillum hungatei. Appl. Environ. Microbiol. 67: 1800-1804.

75. Mouttaki, H., M.A. Nanny \& M.J. MaInerney. 2007. Cyclohexane carboxylate and benzoate formation from crotonate in Syntrophus aciditrophicus. Appl. Environ. Microbiol. 73: 930-938.

76. KASAI, Y. et al. 2005. Physiological and molecular characterization of a microbial community established in unsaturated, petroleum-contaminated soil. Environ. Microbiol. 7: 806-818.

77. Elshahed, M.S. et al. 2001. Metabolism of benzoate, cyclohex-1-ene carboxylate, and cyclohexane carboxylate by Syntrophus aciditrophicus strain SB in syntrophic association with H2-using microorganisms. Appl. Environ. Microbiol. 67: 1728-1738.

78. Duhamel, M. \& E.A. Edwards. 2006. Microbial composition of chlorinated ethene-degrading cultures dominated by Dehalococcoides. FEMS Microbiol. Ecol. 58: 538549.

79. Edwards, E.A. \& D. Grbic-Galic. 1994. Anaerobic degradation of toluene and 0 -xylene by a methanogenic consortium. Appl. Environ. Microbiol. 60: 313-322.

80. Haggblom, M.M., V.K. Knight \& L.J. Kerkhof. 2000. Anaerobic decomposition of halogenated aromatic compounds. Environ. Pollut. 107: 199-207. 
81. Dubourguier, H.C. et al. 1986. Characterization of two strains of Pelobacter carbinolicus isolated from anaerobic digesters. Arch. Microbiol. 145: 248-253.

82. Schink, B. \& M. StiEb. 1983. Fermentative degradation of polyethylene glycol by a strictly anaerobic, gramnegative, nonsporeforming bacterium, Pelobacter venetianus sp. nov. Appl. Environ. Microbiol. 45: 1905-1913.

83. SchinK, B. 1985. Fermentation of acetylene by an obligate anaerobe, Pelobacter acetylenicus sp. nov. Arch. Microbiol. 142: $295-301$.

84. KRumholz, L.R. \& M.P. BRYANT. 1986. Syntrophococcus sucromutans sp. nov. gen. nov. uses carbohydrates as electron donors and formate, methoxymonobenzenoids or Methanobrevibacter as electron acceptor systems. Arch. Microbiol. 143: 313-318.

85. Sekiguchi, Y. et al. 2006. Tepidanaerobacter syntrophicus gen. nov., sp. nov., an anaerobic, moderately thermophilic, syntrophic alcohol- and lactate-degrading bacterium isolated from thermophilic digested sludges. Int. J. Syst. Evol. Microbiol. 56: 1621-1629.

86. Meckenstock, R.U. 1999. Fermentative toluene degradation in anaerobic defined syntrophic cocultures. FEMS Microbiol. Lett. 177: 67-73.

87. Davidova, I.A. et al. 2006. Desulfoglaeba alkanexedens gen. nov., sp. nov., an $n$-alkane-degrading, sulfate-reducing bacterium. Int. J. Syst. Evol. Microbiol. 56: 2737-2742.

88. Zengler, K. et al. 1999. Methane formation from longchain alkanes by anaerobic microorganisms. Nature 401: 266-269.

89. ZiNDER, S.H. \& M. Koch. 1984. Non-aceticlastic methanogenesis from acetate: acetate oxidation by a thermophilic syntrophic coculture. Arch. Microbiol. 138: 263-272.

90. LEE, M.J. \& S.H. ZINDER. 1988. Isolation and characterization of a thermophilic bacterium which oxidizes acetate in syntrophic association with a methanogen and which grows acetogenically on $\mathrm{H}_{2}-\mathrm{CO}_{2}$. Appl. Environ. Microbiol. 54: 124-129.

91. LeE, M.J. \& S.H. Zinder. 1988. Carbon monoxide pathway enzyme activities in a thermophilic anaerobic bacterium grown acetogenically and in a syntrophic acetateoxidizing coculture. Arch. Microbiol. 150: 513-518.

92. Cord-Ruwisch, R., D.R. Lovley \& B. Schink. 1998. Growth of Geobacter sulfurreducens with acetate in syntrophic cooperation with hydrogen-oxidizing anaerobic partners. Appl. Environ. Microbiol. 64: 2232-2236.

93. Schnurer, A., B. Schink \& B.H. Svensson. 1996. Clostridium ultunense sp. nov, a mesophilic bacterium oxidizing acetate in syntrophic association with a hydrogenotrophic methanogenic bacterium. Int. J. Syst. Bacteriol. 46: 1145-1152.

94. HATTORI, S. et al. 2000. Thermacetogenium phaeum gen. nov., sp. nov., a strictly anaerobic, thermophilic, syntrophic acetate-oxidizing bacterium. Int. J. Syst. Evol. Microbiol. 50: $1601-1609$.

95. Zhilina, T.N. et al. 2005. "Candidatus contubernalis alkalaceticum," an obligately syntrophic alkaliphilic bacterium capable of anaerobic acetate oxidation in a coculture with Desulfonatronum cooperativum. Microbiology 74: 800-809.

96. Heijthujjsen, J. \& T.A. Hansen. 1986. Interspecies hydrogen transfer in co-cultures of methanol-utilizing aci- dogens and sulfate-reducing or methanogenic bacteria. FEMS Microbiol. Ecol. 38: 57-64.

97. Cord-Ruwisch, R. \& B. Ollivier. 1986. Interspecific hydrogen transfer during methanol degradation by Sporomusa acidovorans and hydrogenophilic anaerobes. Arch. Microbiol. 144: 163-165.

98. Pantskhava, E.S. \& V.V. Pchyolkina. 1969. Methane fermentation of methanol by Methanobacillus kuznecovii. Appl. Environ. Microbiol. 5: 416-420.

99. Weijma, J. \& A.J. Stams. 2001. Methanol conversion in high-rate anaerobic reactors. Water Sci. Technol. 44: 7-14.

100. BALK, M. et al. 2003. Methanol utilization by a novel thermophilic homoacetogenic bacterium, Moorella mulderi sp. nov., isolated from a bioreactor. Arch. Microbiol. 179: 315-320.

101. BALK, M. et al. 2007. Methanol utilizing Desulfotomaculum species utilizes hydrogen in a methanol-fed sulfatereducing bioreactor. Appl. Microbiol. Biotechnol. 73: 1203-1211.

102. Jiang, B. 2006. The effect of trace elements on the metabolism of methanogenic consortia. Ph.D. thesis, Wageningen University. Wageningen, the Netherlands.

103. Winters, D.K. \& L.G. LJungdahl. 1989. PQQDependent methanol dehydrogenase from Clostridium thermoautotrophicum. In PQQ and Quinoproteins. J. Jongejan \& J.A. Duine, Eds.: 35-39. Dordrecht, The Netherlands: Kluwer Academic Publishers.

104. Thauer, R.K., K. Jungermann \& K. Decker. 1977. Energy conservation in chemotrophic anaerobic bacteria. Bacteriol. Rev. 41: 100-180.

105. Dimroth, P. \& B. Schink. 1998. Energy conservation in the decarboxylation of dicarboxylic acids by fermenting bacteria. Arch. Microbiol. 170: 69-77.

106. Schink, B. \& A.J. M. Stams. 2001. Syntrophism among prokaryotes. In The Prokaryotes: An Evolving Electronic Resource for the Microbiological Community. M. Dworkin, et al., Eds. New York: Springer-Verlag.

107. HatTORI, S. et al. 2005. Operation of the CO dehydrogenase/acetyl coenzyme A pathway in both acetate oxidation and acetate formation by the syntrophically acetateoxidizing bacterium Thermacetogenium phaeum. J. Bacteriol. 187: $3471-3476$.

108. Kosaka, T. et al. 2006. Reconstruction and regulation of the central catabolic pathway in the thermophilic propionate-oxidizing syntroph Pelotomaculum thermopropionicum. J. Bacteriol. 188: 202-210.

109. MaInerney, M.J. et al. 2007. The genome of Syntrophus aciditrophicus: life at the thermodynamic limit of microbial growth. Proc. Natl. Acad. Sci. USA 104: 7600-7605.

110. Scholten, J.C. et al. 2007. Evolution of the syntrophic interaction between Desulfovibrio vulgaris and Methanosarcina barkeri: involvement of an ancient horizontal gene transfer. Biochem. Biophys. Res. Commun. 352: $48-$ 54.

111. DeSantis, T.Z. et al. 2006. Greengenes, a Chimerachecked 16S rRNA gene database and workbench compatible with ARB. Appl. Environ. Microbiol. 72: 5069 72.

112. LUDWIG, W. et al. 2004. ARB: a software environment for sequence data. Nucleic Acids Res. 32: 1363-1371. 